\title{
9. Death by a thousand cuts: privatizing public education in the USA
}

\section{Joanne Barkan}

When market-driven reformers in the United States look at public education, they see two separate activities - the government funds education and the government runs schools. The first is okay with them; the second is not. Reformers want to replace their bête noir-the "monopoly of government-run schools"-with freedom of choice in a competitive market filled with privately-run schools that get government subsidies (Brouillette, 2001). Public funding, private management - the four words sum up American-style privatization whether applied to airports, prisons, or education. In the last twenty years, the "ed-reform" movement has assembled a mixed bag of players and policies, complicated by alliances of convenience and half-hidden agendas. Donald Trump's election, his choice of zealot privatizer Betsy DeVos as US Secretary of Education, and the prospect of more funding from them have energized the movement but also made more Americans wary. What follows is a survey of the controversial movement-where it came from, how it operates, and what it has delivered so far to a nation deeply divided by race and class.

\section{SHIFTING VISIONS OF EDUCATION IN A DEMOCRACY}

In the second half of the nineteenth century, consensus grew around an expansive vision of education in which government would play a far-reaching role: schooling should be government funded and 
administered, universal, and compulsory until a certain age. In a nation that was increasingly industrialized and home to new immigrants, citizens expected public schools to accomplish a great deal, including imparting general knowledge and practical skills, preparing young people psychologically and socially for self-sufficient adult lives, educating for democratic citizenship, unifying a diverse population, and creating opportunity for upward mobility. In time, most Americans came to regard public education as a mainstay of democracy.

The US Constitution makes no mention of education, and so the federal (national) government historically had no specified role to play. Since the earliest days of the republic, local and state authorities shaped elementary and secondary (K-12) public education. Racial segregation in schools-absolute in seventeen states and the norm almost everywhere else-was also a local and state matter. This did not change until 1954 when the US Supreme Court ruled that racially segregated public schools were "inherently unequal" and therefore unconstitutional (Brown v. Board of Education of Topeka). When the federal government stepped in to enforce school desegregation, it met with fierce resistance. After several years of minimal progress, federal authorities resorted to court-ordered desegregation plans, which they imposed on school districts across the country, not only in the South. For the first time, the federal government had assumed a significant role. In the mid-1960s and 1970s, the federal role expanded to include protecting the civil rights of students and offering financial assistance to K-12 public schools with high percentages of low-income students (Patterson, 2001).

In the1980s, the political climate shifted. An international renaissance of laissez-faire economics, updated as "neoliberalism," challenged the dominant Keynesian model of regulated markets (Vincent, 2010). Governments around the world began to act on a suite of neoliberal principles: competition and choice in the free market are the best organizing principles for almost all human activity because they produce greater efficiency and higher quality; the role of government is to provide a framework that allows the market to function freely; most other government activity gums up the system. Ruling elites believed that implementing these principles would solve inflation problems, stagnation, unemployment, low productivity, and whatever else was going wrong in an 
economy. Neoliberalism led logically to specific policies: cut taxes and government spending, deregulate the economy, and transfer as much government activity as possible to the private sector, including education. And if government funding is necessary to get something done, turn management over to the private sector.

The ideological shift to neoliberalism was rapid and widespread. This was the age of Britain's Margaret Thatcher and the US's Ronald Reagan-two world leaders who aimed to revolutionize economic policy at home and abroad. Governments around the world embraced austerity, deregulation, and privatization. Consider, for example, some major nationalized industries that were privatized in the 1980s: British Telecommunications (1984), Spain's car manufacturer, SEAT (1986), New Zealand Steel (1987), Japanese National Railways (1987), Air Canada (1988), to name just a few.

One of neoliberalism's major thinkers and its most successful popularizer was economist Milton Friedman, who advised Republican candidate Reagan during the 1980 presidential campaign and joined his Economic Policy Advisory Board in 1981. On education policy, Friedman never deviated from the model he presented in his 1955 essay, "The Role of Government in Education." He proposed that government get out of the business of running schools altogether. Instead it should fund a voucher worth the same amount of money for every school-age child to use at his or her choice of private school. For Friedman, the choices would include private for-profit schools, private non-profit schools, religious schools, and "some even" run by the government. A democratic society, he reasoned, requires "a minimum degree of literacy and knowledge on the part of most citizens." Hence government has a legitimate interest in requiring and paying for what the community decides will be the "minimum amount of education." But government running schools is not "justifiable in its own right in a predominantly free enterprise society" (Friedman, 1955).

In this marketized system, competition will, theoretically, eliminate low-performing schools because they will not attract enough customers to stay in business. In the real world, the poor buy necessities at a price they can afford even if the quality is inferior. This is why the free market has always failed to meet the real needs of low-income people; they get what they can pay for. In a school voucher system, wealthy families can (and will) add as much money as they want to their vouchers to pay for their choice of 
schools; middle-income families will pull together whatever resources they can for the best schools in their price range. Low-income families without additional resources will "choose" schools charging only the value of the voucher. Almost no higher quality schools will be available because they will have no incentive except altruism to offer their products at the minimum price. ${ }^{1}$ As a last resort, low-income families can enroll their children in a "government school." For free-market ideologues, government schools are always a last resort and available to the poor.

Backtracking for a moment, many Southern states anticipated the 1954 Brown school desegregation decision and prepared policies to evade racial integration. Between 1954 and 1959, eight states adopted what were whites-only versions of Friedman's voucher system (Murphy, 1958). They used public funds to pay for white students to attend all-white private schools, which were called "freedom of choice schools" or "segregation academies." States also leased unused public school property to private schools. Shortly before publication of his 1955 essay, Friedman added a footnote to address the segregationist versions of "essentially this [i.e. his own] proposal." He argued that both forced segregation and "forced non-segregation" were evil. His solution for the South and everywhere else was publicly funded vouchers used for "exclusively white schools, exclusively colored schools, and mixed schools. Parents can choose which to send their children to" (Friedman, 1955). Friedman's essay prefigures the indifference of today's market-driven reformers to racial segregation in education as long as the tradeoff is private schools. The essay still functions as their touchstone (Tooley, 2014).

\section{SOWING THE SEEDS OF MARKET-DRIVEN REFORM}

Education policy advisors in Reagan's administration hoped to wean Americans off "government schools" while also weakening the teachers' unions, which were a significant source of power for

1 In 2016-2017, the value of a government voucher for high school in Washington, DC was $\$ 12,679$; tuition at Washington's elite private schools topped $\$ 40,000$ (Toch and Jordan, 2017). 
the Democratic Party. Starting the weaning process required convincing Americans that public education was failing. In 1983 the administration released A Nation at Risk, a report aimed at generating support for radical reform. The rhetoric was hyperbolic: "the educational foundations of our society are presently being eroded by a rising tide of mediocrity that threatens our very future as a Nation and a people" (National Commission on Excellence in Education, 1983). Apocalyptic claims were backed up by what one researcher called "a golden treasury of spun statistics" (Bracey, 2008). The media hyped the report to the point of stoking a panic about failing schools. Politicians across the political spectrum called for higher standards, better test results, and greater performance accountability from public schools. Conservatives simultaneously aimed for deep spending cuts.

The sky-is-falling panic about public schools and the "standards and accountability" demands attracted bi-partisan support. Neoliberal thinking had influence far beyond ideological devotees. It tinged political moderates, self-identified liberals, media people, and think-tank opinion makers. It permeated what became the dominant wing of the Democratic Party - the "New Democrats." Their jargon included choice, competition, efficiency, and downsizing government; they often competed with Republicans for pro-market credibility (Palley, 2012).

In the 1990s, the growing push for tougher education standards, better test scores, and more accountability coincided with a declining commitment to racial desegregation. Public school integration, on the rise since the mid-1960s, peaked in 1988 when 43.5 percent of all black students attended schools that were at least 50 percent white (Orfield, 2001). Although research showed that integrated schools narrowed the achievement gap between minority and white students without harming the latter (Kirp, 2012), the dedication of most government officials to proactive desegregation had dissipated. Decisions of the US Supreme Court in 1991, 1992, and 1995 made it easier for school districts to abandon their courtordered plans (Donald, 2013). Resegregation began immediately. In just ten years, the percentage of black students attending schools that were at least 50 percent white dropped to 32.7 percent (Orfield, 2001).

Highly segregated schools attended by low-income minority students were notoriously under-resourced compared to public 
schools attended by white middle-class and wealthy students. Many schools in poor urban neighborhoods needed help. Moreover, although the achievement gap between minority and white students had been narrowing, it still existed. Most politicians professed a commitment to reducing racial inequality, but they acted within neoliberal constraints and with no interest in pushing integration further. Glorification of the market along with the vogue for standards and accountability suggested a new approach: government could commit to improving education for low-income minority students with market tools while leaving schools segregated (Orfield, 2001). The mainstream political world seemed to slide easily from the ostensible goal of integration to aiming for something like "separate but improved" for low-income minority children. Government would hold public schools to high standards, use data to determine how well they were doing, and help students in inadequate public schools move to better schools of their choice. The primary measure of school quality would be student scores on standardized tests despite the fact that most education scholars agreed the scores reveal little about education success. Thus the seeds of twenty-first-century market-driven reform were sown.

Neoliberal innovations in education policy took hold slowly. Reagan proposed several voucher-type programs, but they died in Congress. He did, however, cut the federal government's portion of total public education spending from 12 percent to 6 percent (Clabaugh, 2004). The George H.W. Bush administration (19891993) produced no major education laws although some policy ideas were picked up by Bill Clinton (1993-2001). In 1994 Clinton signed the Improving America's Schools Act, which provided federal funds to states to create a new type of school: publicly funded, privately operated "charter schools." They would have more autonomy than district (traditional) public schools and, advocates claimed, be more innovative. The first charter school in the United States had opened in St. Paul, Minnesota, in 1992 under state law (Urahn, 1994). Clinton's Improving America's Schools Act was designed to motivate other states to create these schools and "to increase the number of charter schools nationwide" (US Department of Education, 2000). In 1999 Florida's Governor Jeb Bush (the former president's son) signed into law the nation's first statewide voucher program (Kober, 2000). Still operating, the 
Florida Opportunity Scholarship program allows students in "failing" public schools to use state funds to pay for private schools, including religious schools.

With charter schools and voucher programs, market-driven ed-reformers had the tools they needed. Both policies channel public funding for education to private entities but in different ways. When students receive a government-funded voucher for a set amount of money, they give the voucher to a private or religious school as payment or partial payment for tuition. All the tax-payer funds going to private and religious schools are funds no longer available for public education. In the charter school system, the private entities that run the schools receive an allotment of public funds for each student who enrolls. The money comes out of the budgets for district public schools. The public schools are left with the same fixed expenses but less money and fewer students. They almost inevitably deteriorate: a school that could previously afford a librarian, nurse, full maintenance staff, or smaller classes no longer has enough students to cover costs (Capital \& Main, 2016).

Ed-reformers do not promote vouchers and charter schools to the public as strategies to privatize public education. Instead, they pitch their reforms as ways to create choice in K-12 education. Reformers claim that charter schools and vouchers do nothing more than give low-income students trapped in low-performing schools other choices; they also give all parents the power to choose the schools they know are best for their children (Brouillette, 2001). Who could object? Reformers have successfully made "choice" the subject of the policy debate. A candid description of vouchers and charter schools-for example, these policies drain public funds from public schools and channel the money to private entities, student by student, school by school-would not win much support (see the analysis of public support below). In addition, many centrist and liberal reformers do not have privatization as their goal. They focus on getting as many students as possible out of low-testing schools as quickly as possible. They practice a kind of triage without thinking through the consequences: by steadily draining resources from district public schools, they undermine the very schools that the vast majority of American children still attend. Moreover, in the crusade for choice, reformers have lost sight of the full role of public education in a democracy. 


\section{BUILDING A MOVEMENT FROM THE TOP DOWN}

After the turn of the twenty-first century, market-driven reformers began attracting enough support and funding to build organizations and to operate like, or at least look like, a movement. By 2010 "reform-think" dominated the national conversation on K-12 education. But market-driven reform never became a grassroots movement. It attracted elites: billionaire philanthropists, private mega foundations, finance and high-tech entrepreneurs, politicians at every level of government, business leaders, media figures, and think-tank advocates. The players have been overwhelmingly white; their methods consistently top-down. Notably missing have been teachers, school administrators, parents, and students, most of whom oppose market-driven policies. With elite support, ed-reformers collected enough money to build an ed-reform industry of scores of organizations employing same-thinking researchers, program designers, consultants, lobbyists, campaign organizers, and media producers (Welner, 2013). A cadre of super-wealthy donors regularly gives millions of dollars to pro-ed-reform candidates for state and local offices; they fund ballot initiatives around the country and pour hundreds of thousands of dollars into local school board races. The right-wing American Legislative Exchange Council (ALEC), which drafts model legislation for conservative state lawmakers, has been an important ally of the ed-reform movement. Some states have adopted ALEC model legislation verbatim.

Help also came from the White House. George W. Bush (20012009) advanced both charter schools and vouchers. His signature education law, No Child Left Behind (signed in 2002), established that students in low-performing, low-income public schools could transfer within their district to another public school or to a charter school (US Department of Education, 2007). In 2004 Bush signed into law a voucher program that Congress designed for Washington, DC (Congress retains much authority over the District of Columbia, which is not a state.) The DC Opportunity Scholarship Program offers every low-income student in DC a federally funded voucher to use at a participating private school, including religious schools (Wolf et al., 2010).

Barack Obama (2009-2017) opposed school vouchers, but he quickly became Charter-Advocate-in-Chief. In the depths of the 
"great recession" in 2009, his Department of Education (DOE) launched a $\$ 4.35$ billion competitive grant program called Race to the Top. The rules stipulated that each competing state submit a public school reform plan, taking into account a long list of DOE pet policies. States that scored highest on the DOE's point system would win millions of dollars to implement their plans. DOE criteria included not limiting the growth of charter schools (some states had capped the number). States were also required to give charter schools free use of public facilities or help them pay for facilities (US Department of Education, 2009). Public school supporters fiercely opposed the measures because they diverted resources from already stretched-to-the-limit education budgets. But state governments were desperate for money from anywhere; all but four eventually entered the contest. Obama's Race to the Top gave the entire charter school enterprise a substantial boost.

Charter schools claim to be public schools because they receive tax-payer money and, in theory, are overseen by state-appointed authorities. But private-sector entities-either boards or charter management organizations (CMOs) - run the schools and control finances. ${ }^{2}$ Private management, which can be for-profit or nonprofit, allows charter schools to avoid the transparency and accountability required of district public schools. When the public or press asks for documentation, managers can claim private status. They regularly refuse access to their financial records, data, and internal communications-information that public entities are required to make available. In September 2017, for example, investigative reporters requested some emails from Eva Moskowitz, CEO of Success Academy Charter Schools, Inc., a CMO that runs forty-six schools in New York City. The company's lawyer responded that the CMO "is not itself a charter school or a government agency ... it is not in and of itself subject to FOIL [Freedom of Information Law] or required to have an appeal process" (Disare, 2017). Charter school operators prefer as little public supervision as possible. Predictably, inadequate transparency and accountability have led to widespread malfeasance in the sector (more on this below).

Reformers also champion virtual (online) schools, most of which are privately run, for-profit, and notably lucrative. They use the

2 Only about 10 percent of charter schools are unionized (Loewus, 2017). 
same funding mechanism as charter schools - the operators get public funds for each child who signs up-but they do not have to maintain buildings, provide transportation, or pay for full staff. One teacher can follow scores, even hundreds, of students as they tap their way through digital lessons on their home computers.

According to the National Alliance for Public Charter Schools (2017), charter enrollment increased from 1.2 million students in 2006-2007 to an estimated 3.1 million in 2016-2017. The number of charter schools reached more than 6,900. These numbers look tiny compared to the overall size of the US K-12 system. For example, the federal government projected that about 50.7 million students would attend public and charter schools in fall 2017; about 5.2 million would attend private schools (National Center for Education Statistics, 2017). In addition, about 1.7 million were homeschooled in 2016 (McQuiggan and Megra, 2017). But charters schools are highly concentrated geographically and wield substantial political clout. They enroll 20 percent or more of all students in 44 districts around the country, including major cities. ${ }^{3}$ Some 92 percent of K-12 students in New Orleans attend charter schools; 53 percent in Detroit; 45 percent in the District of Columbia (National Alliance for Public Charter Schools, 2016). Charter networks run well-funded lobbying efforts in most states. As of November 2017, only six states did not allow charter schools (The 74, 2017).

\section{ANATOMY OF TWO REFORMS: CHARTER SCHOOLS AND VOUCHERS}

To justify the existence of charter schools, ed-reformers have always claimed they outperform the district public schools that most low-income and minority students attend. Indeed, unless charters perform better, they serve no purpose other than choice for the sake of choice regardless of quality. Both government and ed-reformers still rely on student scores on standardized tests to measure performance. Since 2009 a pro-privatization research center at Stanford University has regularly conducted national

\footnotetext{
3 There are about 13,600 public school districts in the USA. The largest take in entire cities, such as New York City and Los Angeles. The smallest include just one school (National Center for Education Statistics, 2017).
} 
studies comparing the test scores of charter school students to the scores of demographically similar students at district public schools (Center for Research on Education Outcomes, 2009-2017). Over the years, the studies have generated a consistent, albeit rough, picture of average performance nationwide: about one half of all charters perform at the same level as district schools, about one quarter perform worse, and about one quarter perform better. In 2016 a comprehensive study of charter schools in Texas by the respected National Bureau of Economic Research found that "at the mean, charter schools have no impact on test scores and a negative impact on [future] earnings" (Dobbie and Freyer, 2016). These mediocre results fall far short of reformers' claims and hardly justify undermining district schools.

As for high-performing charter schools, research has shown they boost test scores by "counseling out" the most challenging students - those with cognitive and physical disabilities, behavior problems, and English language learners. These students remain in district schools, increasing the concentration of at-risk students in precisely the districts that have lost funding to charter schools. In the 2013-2014 school year, the Budget, Facilities, and Audit Committee of the Los Angeles Unified School District (LAUSD) reported that 1.2 percent of charter school students were severely disabled; the figure for LAUSD overall was 3.8 percent-more than three times as large (Reilly and Reed, 2016).

Turning to vouchers, the goal of staunch advocates is to replicate the system that Milton Friedman proposed in 1955: a tax-payer voucher for every student to use in a free market of private and religious schools. Although several states offer vouchers to all families, rich and poor, public support for "universal" programs like these is low. To get around this obstacle, reformers have advocated programs limited to low-income students, students in lowperforming schools, or students with special needs. They also devised several variations on vouchers, all of which channel public funds to private schools but avoid the unpopular "v" word. "Privateschool tuition tax credits" allow families to subtract the cost of tuition from the taxes they pay; "tax-credit scholarships" give tax credits to donors (corporations included) who fund scholarships for other people's children to attend private or religious schools. Donors cycle their money through non-profit "school tuition organizations" (STO). Rerouting the money, reformers argue, prevents 
any violation of the separation of church and state: the STO "middleman" separates the government funding (the tax credit) from the religious institution. In reality, the process works like money laundering: funds pass through a private entity and arrive at a religious school scrubbed clean of their tax-payer origin. Another privatizing tool-"education savings accounts"-gives families government-funded debit cards to use for various private education expenses in addition to tuition.

According to the Milton and Rose Friedman Foundation, which changed its name in 2016 to the less politically charged EdChoice ("Changes Name," 2016), there were 64 voucher and voucher-type programs, including tax-credit plans in 30 states and the District of Columbia as of January 2018 ("School Choice," 2018). Most of the money ends up at religious schools. For example, 82 percent of the nearly 100,000 students in the Florida Tax Credit Scholarship Program chose religious schools in 2017 (Florida Department of Education, 2017). Republicans, who control a large majority of state governments as well as the White House and Congress, aim to expand voucher programs. Paradoxically, the promised expansion comes shortly after the release of several studies showing that voucher programs actually hurt student performance. In late 2015, for example, researchers reported that Indiana's "voucher students who transfer to private schools experienced significant losses in achievement" in math and no improvement in reading (Carey, 2017, February 23). In June 2016, a study of a large Ohio voucher program, published by the pro-reform Thomas B. Fordham Institute, found: "The students who use vouchers to attend private schools have fared worse academically compared to their closely matched peers attending public schools ... Such impacts also appear to persist over time" (Churchill and Aldis, 2016).

Voucher supporters (Milton Friedman included) have always assumed that transferring from a public school to a private school means transferring to a better school. But in recent years, public schools in the United States have closed the achievement gap with private schools (Dynarski, 2016). Since government vouchers never cover the cost of higher quality private schools, most low-income students end up at schools that are either no better or even worse academically than the public schools they left. 


\section{ACADEMIC FAILURE, CORRUPTION, SEGREGATION-AND BEYOND}

Both charter school management and voucher programs are rife with fraud. It comes with the territory when states hand out millions of dollars without adequate vetting or ongoing oversight. The pro-public-school Network for Public Education posts a useful feature on its website called \#ANOTHERDAYANOTHERCHARTERSCANDAL, which keeps a running account of charter misconduct along with links to source material (https://networkfor publiceducation.org/9734-2/). Here are a few recent scandals: The founder and former administrator of Southwest Learning Centers, which ran four charter schools in Albuquerque, NM, pleaded guilty to pocketing over $\$ 2$ million in several common charter scams. His schools paid fake invoices to a fake company he set up in Las Vegas; parents paid for online credits that their children never earned; he leased a building for his schools and charged them double the actual rent (Carl, 2017).

The Pennsylvania Ethics Commission fined the former CEO of the defunct Pocono Mountain Charter School in Coolbaugh Township for four years of deficient financial statements. The commission also cited him for asking the charter board to raise his wife's salary at the school and to hire his children for school positions (Frank, 2017). The former principle of a Delaware charter schoolthe Academy of Dover-pleaded guilty to embezzling $\$ 145,480$. The case went to federal court "due to the significant funding received by the Academy of Dover" (Anderson, 2017).

Voucher corruption looks like this: The Arizona Christian School Tuition Organization (ACSTO) is one of the largest groups in the state that grants tax credit scholarships for private schools. From 2010 to 2014, donors contributed \$72.9 million to ACSTO. Arizona law allows families of all income levels to use the vouchers; it also allows voucher granting groups to keep 10 percent of all donations to cover overheads. ACSTO's founder and executive director, Steve Yarbrough, is also president of the Arizona State Senate and a longtime voucher promoter. ACSTO outsources much of its workfrom data entry to customer service- to HY Processing, a private for-profit company owned by Yarbrough, his wife, and another couple. ACSTO pays $\$ 52,000$ a year in rent to its landlord-also 
Yarbrough. In 2012 Yarbrough bought a \$16,000 car; ACSTO reimbursed him for the full amount (Carey, 2017, March 2).

Vouchers and charter schools create still another problem: they increase racial and socio-economic segregation. A March 2017 report by the Century Foundation analyzes longitudinal data from studies of the Milwaukee Parental Choice Program (2010) and the Louisiana Scholarship Program (2017). In Milwaukee 68.4 percent of voucher-participating private schools had enrollments that were either 90 percent white or 90 percent black. Overall, 90 percent of voucher transfers "increased segregation in private schools, public schools, or both sectors." In Louisiana, 76 percent of white voucher users left public schools where white students were underrepresented; 72 percent of them moved to schools where whites were overrepresented. Meanwhile, 82 percent of black students who used vouchers left public schools where blacks were overrepresented; 55 percent of them ended up at private schools where blacks were again overrepresented (Potter, 2017). According to a 2016 comprehensive report by the Brookings Institution, "charter schools enroll more black and poor students than traditional public schools in the same areas and are more likely to be at one extreme or the other of the racial and economic demographic spectrum than traditional public schools" (Grover, Reeves, and Rodrigue, 2016).

Academic failures, recurrent corruption, increased segregationyet market-driven reformers rarely confront these problems publicly or reexamine their assumptions. Ideology rules their perspective: public education is a repressive government monopoly, period. A December 2017 Associated Press analysis detailed how charter schools "are vastly over-represented among schools where minorities study in the most extreme racial isolation." The report quotes the response of the spokesperson for the National Alliance for Public Charter Schools: "Modern schools of choice with high concentrations of students of color is [sic] a demonstration of parents choosing the best schools for their children ... This is not segregation" (Moreno, 2017).

Despite two decades of controversy around market-driven reforms, Americans remain woefully uninformed. According to a 2017 poll by the independent research company SSRS, a little more than half of Americans support charter schools until they learn that the funding is taken from district public schools. Then support 
plummets to 30 percent (Hefling, 2017). In the 2017 survey conducted by the pro-reform journal Education Next, support for vouchers hinged on whether the survey questions contained the phrase "wider choice" or "use government funds." A proposal to "give all families with children in public schools a wider choice, by allowing them to enroll their children in private schools instead, with government helping to pay the tuition" received 45 percent support. A proposal to "use government funds to pay the tuition of all students who choose to attend private schools" received only 27 percent support (Education Next, 2017). ${ }^{4}$ Most Americans oppose charters and vouchers when they know that the policies drain funds from public schools. Much of the success of the market-driven reform movement has depended on their not knowing.

The Trump-DeVos regime has just begun to implement its anti-public education agenda. The December 2017 overhaul of the federal tax code incentivizes privatization by allowing families that have tax-free savings accounts for college expenses to apply that money to K-12 private school tuition and homeschooling (Balingit and Douglas-Gabriel, 2017). The Trump-DeVos budget proposal for fiscal year 2018 cuts the Department of Education (DOE) budget by 13.6 percent, undermining programs for teacher training, salaries, and afterschool activities for low income children. The proposal includes a 40 percent staff cut for the DOE's Office for Civil Rights while a new expenditure of $\$ 250$ million would create a federally funded, nationwide school voucher program (Whitaker, McDaniels, and Johnson, 2017). Trump and DeVos campaign around the country for market-driven reforms and candidates who support them, but the true juggernaut behind ed-reform remains the state governments. As of January 2018, Republicans controlled a near-record thirty-two state legislatures and thirty-four governorships. Education policy is mostly in their hands. Right-wing Republicans established a lock on power after the 2010 elections by overseeing the redrawing of electoral districts in many states (Ohlemacher, 2014).

Draining resources from public schools has already undermined school districts around the country. If this continues, the death of

4 Neither question contained the politically charged word "voucher." 
public education by a thousand cuts will be a reality long before privatization is complete. With Republican and Democratic ed-reformers dominant in so many states and school districts, opponents have not been able to win across-the-board pro-public education programs. Instead, they have to combat market-driven reforms one legislative proposal at a time, one ballot measure at a time, one school board election at a time. Battles can last for years; most require relentless grassroots efforts. Here is what a victory for public education looks like:

In 2011 the pro-ed-reform school board of Douglas County, the wealthiest county in Colorado, created the nation's only districtauthorized, universal voucher program. A parents group called Taxpayers for Public Education went to court to block it. In 2015 the Colorado Supreme Court declared the program unconstitutional because state tax dollars cannot be used for religious schools. The school district appealed to the US Supreme Court, using \$1.8 million from the conservative Walton Family Foundation and the Daniels Fund to cover legal expenses. In June 2017, the US Supreme Court directed the Colorado Supreme Court to revisit the case. But Douglas County voters, angry about the deterioration of their schools under the ed-reformers, acted first. In November 2017, they elected a pro-public education slate of candidates to the school board. In December the new board voted to abolish the voucher program, six to zero (Goodland, 2017).

Until market-driven ed-reformers lose power, the survival of public education in the United States depends on informed citizens organizing for victories like the one in Douglas County.

\section{REFERENCES}

Anderson, C. (2017, November 21). Former Academy of Dover Principal Pleads Guilty in Fraud Case. Delaware State News. Retrieved on January 28, 2018 from https://delawarestatenews.net/schools/former-academy-doverprincipal-pleads-guilty-fraud-case/.

Balingit, M. and Douglas-Gabriel, D. (2017, December 18). Here's What the GOP's Proposal to Overhaul the Tax Code Means for Schools, Students and Parents. The Washington Post. Retrieved on January 28, 2018 from https:// www.washingtonpost.com/news/education/wp/2017/12/15/heres-what-thegops-proposal-to-overhaul-the-tax-code-means-for-schools-students-andparents/?utm_term $=.67 \mathrm{cec} 35 \mathrm{e} 373 \mathrm{c}$. 
Bracey, G. (2008, Fall). Disastrous Legacy: Aftermath of A Nation at Risk. Dissent, 80-83. Retrieved on January 28, 2018 from https://www.dissent magazine.org/article/disastrous-legacy-aftermath-of-a-nation-at-risk.

Brouillette, M.J. (2001, January 29). Conclusion: Restoring a Free Market in Education. The Case for Choice in Schooling. Retrieved on January 28, 2018 from https://www.mackinac.org/3243.

Capital \& Main. (2016, June 1). Failing the Test: Charter Schools' Winners and Losers. Capital \& Main. Retrieved on January 28, 2018 from https://capital andmain.com/failing-the-test-charter-schools-winners-and-losers-0601.

Carey, K. (2017, February 23). Dismal Voucher Results Surprise Researchers as DeVos Era Begins. The New York Times. Retrieved on January 28, 2018 from https://www.nytimes.com/2017/02/23/upshot/dismal-results-fromvouchers-surprise-researchers-as-devos-era-begins.html?_r=1.

Carey, K. (2017, March 2). DeVos and Tax Credit Vouchers: Arizona Shows What Can Go Wrong. The New York Times. Retrieved on January 28, 2018 from https://www.nytimes.com/2017/03/02/upshot/arizona-shows-what-cango-wrong-with-tax-credit-vouchers.html?emc=edit_tnt_20170302\&nlid=342 $74273 \&$ tntemail0 $=\mathrm{y}$.

Carl, D. (2017, October 25). Former charter school leader pleads guilty to fraud (video transcript). KOAT-7-ABC. Retrieved on January 28, 2018 from http://www.koat.com/article/former-charter-school-leader-pleads-guilty-tofraud/13091098.

Center for Research on Education Outcomes (CREDO). (2009-2017). Charter School Studies. Links to studies available from https://credo.stanford.edu/ research-reports.html.

Changes Name to EdChoice. (2016, July 29). Retrieved on January 28, 2018 from https://www.edchoice.org/media/friedman-foundation-changes-nameedchoice/.

Churchill, A. and Aldis, C. (2016, July). Foreword. In D. Figlio and K. Karbownik (eds), Evaluation of Ohio's EdChoice Scholarship Program: Selection, Competition, and Performance Effects (p. 2). Columbus, OH: Thomas B. Fordham Institute. Retrieved on January 28, 2018 from https:// edex.s3-us-west-2.amazonaws.com/publication/pdfs/FORDHAM Ed Choice Evaluation Report_online edition.pdf.

Clabaugh, G.K. (2004). The Educational Legacy of Ronald Reagan. Educational Horizons, 82(4), 256-259. Retrieved on January 28, 2018 from https://files.eric.ed.gov/fulltext/EJ684842.pdf (also see http://www.jstor.org/ stable/42926508).

Disare, M. (2017, September 21). Private Managers of Public Schools, Charter Leaders Enjoy Extra Buffer From Public-Records Laws. Chalkbeat. Retrieved on January 28, 2018 from https://www.chalkbeat.org/posts/ny/ 2017/09/21/private-managers-of-public-schools-charter-leaders-enjoy-extrabuffer-from-public-records-laws. 
Dobbie, W.S. and Freyer, R.G. Jr. (2016). Charter Schools and Labor Market Outcomes (NBER Working Paper No. 22502). Retrieved on January 28, 2018 from http://www.nber.org/papers/w22502.pdf.

Donald, B. (2013, August 7-11). Timeline of Supreme Court SchoolDesegregation Cases from Brown to Fisher, presented at The American Bar Association Annual Meeting, San Francisco, 2013. Retrieved on January 28, 2018 from https://www.americanbar.org/content/dam/aba/administrative/ litigation/materials/aba-annual-2013/written_materials/20_lessons_in_leader ship.authcheckdam.pdf.

Dynarski, M. (2016, May 26). On Negative Effects of Vouchers (Evidence Speaks Reports Vol.1, No.18). Retrieved on January 28, 2018 from http:// www.brookings.edu/research/reports/2016/05/26-on-negative-effects-of-schoolvouchers-dynarski.

Education Next. (2017). Tables 13a, b, c and d. In Program on Education Policy and Governance-Survey 2017 (pp. 12-13). Retrieved on January 28, 2018 from http://educationnext.org/files/2017ednextpoll.pdf.

Florida Department of Education. (2017). Florida Tax Credit Scholarship Program (June 2017 Quarterly Report). Retrieved on January 28, 2018 from http://www.fldoe.org/core/fileparse.php/7558/urlt/FTC-June-2017-Q-Report 2.pdf.

Frank, H. (2017, November 8). Former Charter School CEO Fined \$55k. Pocono Record. Retrieved on January 28, 2018 from http://www.pocono record.com/news/20171108/former-charter-school-ceo-fined-55k.

Friedman, M. (1955). The Role of Government in Education. In R.A. Solo (ed.), Economics and the Public Interest (pp. 123-144). New Brunswick, NJ: Rutgers University Press. Retrieved on January 28, 2018 from http:// la.utexas.edu/users/hcleaver/330T/350kPEEFriedmanRoleOfGovttable.pdf.

Goodland, M. (2017, December 4). Douglas County School Board Ends Controversial Voucher Program. Colorado Politics. Retrieved on January 28, 2018 from https://coloradopolitics.com/douglas-county-school-board-endscontroversial-voucher-program/.

Grover, J., Reeves, R.V. and Rodrigue, E. (2016, October). Segregation, Race, and Charter Schools: What Do We Know? Washington, DC: Center on Children and Families at the Brookings Institution. Retrieved on January 28, 2018 from https://www.brookings.edu/wp-content/uploads/2016/10/ccf_2016 1021segregation_version-10_211.pdf.

Hefling, K. (2017, May 3). Politico-Harvard Poll: Americans Favor Charter Schools-But Not At Public Schools' Expense. Retrieved on January 28, 2018 from https://www.politico.com/story/2017/05/03/politico-harvard-pollamericans-favor-charter-schools-but-not-at-public-schools-expense-237940.

Kirp, D.L. (2012, May 19). Making Schools Work. The New York Times. Retrieved on January 28, 2018 from http://www.nytimes.com/2012/05/20/ opinion/sunday/integration-worked-why-have-we-rejected-it.html.

Kober, N. (2000). School Vouchers: What We Know and Don't Know ... And How We Could Learn More. Washington, DC: Centre on Education Policy. 
Retrieved on January 28, 2018 from https://ia801301.us.archive.org/8/items/ ERIC_ED468514/ERIC_ED468514.pdf.

Loewus, L. (2017, June 30). More Charter School Teachers See Unions as an Option: Organizing slow, uncertain in the sector's schools. Education Week. Retrieved on January 28, 2018 from https://www.edweek.org/ew/articles/ 2017/06/30/at-big-city-charter-schools-more-teachers-see.html.

McQuiggan, M. and Megra, M. (2017). Parent and Family Involvement in Education: Results from the National Household Education Surveys Program of 2016 (NCES 2017-102). Washington, DC: US Department of Education, National Center for Education Statistics. Retrieved on January 28, 2018 from https://nces.ed.gov/pubs2017/2017102.pdf.

Moreno, I. (2017, December 3). US Charter Schools Put Growing Numbers in Racial Isolation. Associated Press News. Retrieved on January 28, 2018 from https://apnews.com/e9c25534dfd44851a5e56bd57454b4f5.

Murphy, W.F. (1958). Private Education with Public Funds? The Journal of Politics, 20(4), 635-654. Retrieved on January 28, 2018 from http://www. journals.uchicago.edu/doi/pdfplus/10.2307/2126801.

National Alliance for Public Charter Schools. (2016). A Growing Movement: America's Largest Charter Public School Communities and Their Impact on Student Outcomes (Report Eleventh Annual Edition). Washington, DC: author. Retrieved on January 28, 2018 from http://www.publiccharters.org/ sites/default/files/migrated/wp-content/uploads/2016/11/

CharterSchoolEnrollmentShareReport2016.pdf.

National Alliance for Public Charter Schools. (2017). Estimated Charter Public School Enrollment, 2016-17 (Report). Washington, DC: author. Retrieved on January 28, 2018 from http://www.publiccharters.org/sites/ default/files/migrated/wp-content/uploads/2017/01/EER_Report_V5.pdf.

National Center for Education Statistics. (2017). Fast Facts: Back to School Statistics. Retrieved on January 28, 2018 from https://nces.ed.gov/fastfacts/ display.asp? $\mathrm{id}=372$.

National Commission on Excellence in Education. (1983). A Nation at Risk: The Imperative for Educational Reform. An Open Letter to the American People. A Report to the Nation and the Secretary of Education. Washington, DC: Department of Education. Retrieved on January 28, 2018 from https:// files.eric.ed.gov/fulltext/ED226006.pdf.

Ohlemacher, S. (2014, March 31). GOP Gerrymandering Creates Uphill Fight for Dems in the House. Associated Press. Retrieved on January 28, 2018 from https://www.pbs.org/newshour/politics/gop-gerrymandering-creates-up hill-fight-dems-house.

Orfield, G. (2001, July). Schools More Separate: Consequences of a Decade of Resegregation. Cambridge, MA: The Civil Rights Project, Harvard University. Retrieved on January 28, 2018 from https://civilrightsproject.ucla. edu/research/k-12-education/integration-and-diversity/schools-more-separateconsequences-of-a-decade-of-resegregation/orfield-schools-more-separate2001.pdf. 
Palley, T.I. (2012). From Financial Crisis to Stagnation: The Destruction of Shared Prosperity and the Role of Economics. New York: Cambridge University Press.

Patterson, J.T. (2001). Brown v. Board of Education: A Civil Rights Milestone and Its Troubled Legacy. New York: Oxford University Press.

Potter, H. (2017, March 21). Do Private School Vouchers Pose a Threat to Integration? Washington, DC: The Century Foundation. Retrieved on January 28, 2018 from https://tcf.org/content/report/private-school-voucherspose-threat-integration/.

Reilly, M.K. and Reed, D.N. (2016, January 19). Establishment of All-Charter Districts: Waivers and Autonomies and Fiscal Impact. Presentation to the Budget, Facilitates, and Audit Committee, Los Angeles Unified School District. Retrieved on January 28, 2018 from https://boe.lausd.net/sites/ default/files/01-19-16BFAAllCharterDistrictPresentation.pdf.

School Choice in America Dashboard. (2018, January 16, last modified). Retrieved on January 28, 2018 from https://www.edchoice.org/schoolchoice/school-choice-in-america/.

The 74. (2017, March 22). After Heated Partisan Battle, Kentucky Is 44th State to Pass Charter Law. Retrieved on January 28, 2018 from https://www. the74million.org/article/after-heated-partisan-battle-kentucky-is-44th-stateto-pass-charter-law/.

Toch, T. and Jordan, P.W. (2017, September 1). The Weakness In D.C.'s Voucher Program. The Washington Post. Retrieved on January 28, 2018 from https://www.washingtonpost.com/opinions/the-weakness-in-dcs-voucherprogram/2017/09/01/09a61694-8cd5-11e7-84c0-02cc069f2c37_story.html?t id=ss_mail\&utm_term=.48220918d51a.

Tooley, J. (2014). "The Role of Government in Education" Revisited: The Theory and Practice of Vouchers, with Pointers to Another Solution for American Education. Social Philosophy and Policy, 31(1), 204-228.

Urahn, S. (1994, December). Minnesota Charter Schools: A Research Report. St. Paul, MN: Minnesota House of Representatives, Research Department. Retrieved on January 28, 2018 from https://files.eric.ed.gov/fulltext/ED 380872.pdf.

US Department of Education, Office of the Under Secretary, Planning and Evaluation Service, Elementary and Secondary Education Division. (2000). Evaluation of the Public Charter Schools Program: Year One Evaluation Report (DOC \#2001-06). Washington, DC: author. Retrieved on January 28, 2018 from https:/www2.ed.gov/rschstat/eval/choice/pcsp-year1/year1report. pdf.

US Department of Education. (2007). No Child Left Behind and Charter Schools: Giving Parents Information and Options. Washington, DC: author. Retrieved on January 28, 2018 from https://www2.ed.gov/nclb/choice/ charter/nclb-charter.html.

US Department of Education. (2009). Race to the Top: Executive Summary. Washington, DC: author. Retrieved on January 28, 2018 from https:// www2.ed.gov/programs/racetothetop/executive-summary.pdf. 
Vincent, A. (2010). Modern Political Ideologies (3rd edition). Chichester, West Sussex: Wiley-Blackwell.

Welner, K. (2013). Free Market Think Tanks and the Marketing of Education Policy. In M. B. Katz and M. Rose (eds), Public Education Under Siege (pp. 67-74). Philadelphia, PA: University of Pennsylvania Press.

Whitaker, C., McDaniels, A. and Johnson, S. (2017, November 20). The Trump Administration's Slow But Steady Undoing of the Department of Education. Retrieved on January 28, 2018 from https://www.americanprogress.org/ issues/education-k-12/news/2017/11/20/442737/trump-administrations-slowsteady-undoing-department-education/.

Wolf, P., Gutmann, B., Puma, M., Kisida, B., Rizzo, L., Eissa, N., and Carr, M. (2010). Evaluation of the DC Opportunity Scholarship Program: Final report (NCEE 2010-4018). Retrieved on January 28, 2018 from http:// eric.ed.gov/?id=ED510451. 